\title{
University Matriculation Examinations as Predictor of First Year Academic Performance of Students in Public Universities inEdo State
}

\author{
Dr. F. Egberha \\ Department of Educational and Counselling Psychology \\ Faculty of Education, University Of Benin, Benin City \\ Dr.(Mrs) J.H. Osarumwense \\ Department of Educational and Counselling Psychology \\ Faculty of Education, University Of Benin, Benin City
}

\begin{abstract}
The study examined University Matriculation Examinations as predictor of first year academic performance of students in public universities Edo State. The study aimed to find the prediction of unified Tertiary Matriculation Examination (UTME) post unified Tertiary Matriculation Examination (PUTME) and post UTME aggregate scores on students' first year academic performance it also investigated which of the predictor has the highest predictive value. The study was guided be (04) research question and (03) hypotheses were tested at 0.05 alpha level. The study employed a correction survey designed which was based on the frame work of export facto. The population of the study was 22,653 students made up first year students of 2012/2013 and 2013/2014 admitted into University of Benin, Benin City and Ambrose Alli University, Ekpoma both in Edo State. The step-wise multistage sampling technique which involve various stages was employed and a sample size of 1500 was used for the study. A proforma titled intuition and students Data proforma (ISDP) was used for data collection. The data collection were analyzed using simple linear regression statistics Finding of the study revealed that UTME, PUTME and post-UTME aggregate scores significantly predicted students first year academic performance as each explained $0.9 \% \quad 4 \%, 10.1 \%$ of the total variance of students' performance respectively. Based on the finding of this study it was recommended were made among others: that PUTME screening test should continue side by side with UTME examination and that use of average of UTME and PUTME known as aggregate score be retained and improved upon.
\end{abstract}

Keywords: UTME, PUTME post-UTME aggregate scores JAMB and first year students'

DOI: $10.7176 / \mathrm{JEP} / 10-15-12$

Publication date:May $31^{\text {st }} 2019$

Background to the study

University Matriculation Examination (UME) now known as Unified Tertiary Matriculation Examination (UTME) is a common entrance examination conducted annually by the Joint Admission and Matriculation Board (JAMB) of Nigeria yearly for the purpose of selecting and placing suitably qualified candidates into Nigerian Universities. The most objective way of determining if a student had learnt is by conducting test. Different countries of the world have different selection procedures for admission into their universities. In Nigeria the prerequisite for admission is set by the National University Commission (NUC). Apart from obtaining acceptable scores in Unified Tertiary Matriculation and Post Unified Tertiary Matriculation Examinations, candidates must obtain credit level pass in at least five relevant subjects which could be obtained at not more than two sittings for most universities.

Academic performance is a manifestation of acquired knowledge, skills and concepts of ideas learnt overtime. Academic performance is a scholastics standing of a student at a given moment. This scholastic standing may be exemplified in grades obtained in a course or group of courses taken. The tendency that student will pass or fail in future task basedon the present or earlier achievement is referred to as predictive validity. When an individual score in a test is used to predict his future performance in another test which measures a similar criterion, the test is said to have predictive validity.

Many studies have been carried out by researchers on entry qualifications as a predictor of academic performance of undergraduate students in public and private universities in Nigeria. Adeyemi (2009) carried out a study on mode of entry as a predictor of success in five years bachelor of education degree examination in Ekiti and Ondo States, Nigeria. The study used education management students of the Universities. The findings revealed that there was a significant relationship between students' mode of entry into the Universities and obtaining CGPA of 3.5 and above in the final 400 level bachelor of education degree among admission though the direct entry, UME and pre-degree programme. The study also revealed that admission through pre-degree was the best predictor of student's success.

Omodara (2010) assessed the predictive validity of UME scores on academic performance of university 
undergraduates of the university of Ado-Ekiti, Nigeria. The study employed correlation and Regression Analysis Statistics. The correlated the UME scores and the Cumulative Grade Point Average (CGPA) of 300 level students who got admission into the university with who 2004 UME results. The finding revealed that that the predictive strength of UME scores on academic performance, and recommend that JAMB should improve on the methods of administration of the UME so as to guide universities to admit students who will perform well in their respective courses.

Ifedili and Ifedili (2010) did a study involving the predictive power of UME at the University of Benin to determine the effectiveness of UME and PUME. The result of the study suggested the supremacy of PUME over UME in selecting best students for University education. Owie(2010) did a study on the contributions of SSCE, UME and PUME to the survival of Nigeria undergraduates. He captioned the study National Examinations as predictors of University survival among undergraduates. His findings revealed that these examinations add little of nothing to University survival. He called them waste of resources and unnecessary diffusion of intellectual focus.

Ajaja, (2010) carried out a study to monitor the performances of sciences education students admitted through post UME screening exercise since its inception in 2005/2006. He employed the expost-facto research design in his study. Samples of 214 students were drawn from all students that were admitted in 2005/2006 academic session. These were students that were admitted into Biology, Chemistry, Mathematics and Physics Education Departments. His sample comprised two groups of students: group one was those admitted in 2004/2005 with UME alone, while group two was made up of students who were admitted in 2005/2006 with UME and PUME. Ajaja's interest was in their performances from 100 to 300 level. He examined their performances looking at how many of them were in various classes of degree from 100 to 300 level.His findings revealed that Post-UME screening exercise did not do better than UME in terms of influencing students' academic performance.

Obioma and Salau (2014) did a study to investigate the extent to which scores in examination conducted by WAEC, NABTEB, NECO and JAMB predict future academic performance of students in University degree examination. The study made use of records of performance in public examination of 4,904 undergraduates drawn from 22 Universities across the country.

In addition students' academic records in eight (8) core subjects were also used. The criterion variable was the Cumulative Grade Point Average (CGPA) of the students. The findings of the study among others revealed that UME was the least predictor accounting for $1.5 \%$ of the variance in year one CGPA and $0.6 \%$ of explained variance in the final year CGPA. Though the results of the study also revealed that WASSCE was the best predictor of students' CGPAObioma and Salau (2014) concluded that general public examinations were poor predictors of students University academic achievement.

\section{Statement of the Problem}

The quality of students' performance in examinations/tests remains a top priority for educators, government, parent/guardians and even students. Consequently parents/guardians go extra mile in investing so much money time and energy on their children also, government and corporate bodies invest so much on the education sector. One important fact about test scores or examination results is their ability to predict future performance oftestees especially in related study. However, there has be an outcry over poor academic performance of many undergraduate students in Nigeria Universities. This was probably one of the reasons for the introduction of PostUME screening exercise into Nigerian Universities in 2005/2006 academic session. However, the introduction of Post-UME screening exercise did not go down well with JAMB. It fought tirelessly against the introduction of Post- UME. In this regard, the federal government in 2008/2009 admission exercise compelled Universities to make use of UME and PUME scores for the admission of students. This is what is known as "aggregate score". Aggregate score is the sum of $1 / 8$ or 12.5 of candidates JAMB scores and $1 / 2$ or $50 \%$ of PUME scores. This is the score that is presently use for selecting students into Nigerian Universities.

According to Afemikhe (2008), PUME was introduced into Nigeria Universities as a result of public outcry of the fallen standard in education which was measured by the performance of students and the many carry-over courses students have after their 100 level. The poor performance of some students is also demonstrated by products of Nigerian Institutions in the world of work after graduation. Besides, many stakeholders in education have opined that University students' performance do not always reflect their pre-admission academic performance such as WAEC and PUME scores (Opoko, Alagbe, Aderonmu, Ezema\&Oluwatayo, 2014.)

At present the problem affirmed by Opokoet al (2014) are still very much with us as many undergraduate students still do not do well in their courses. Some students spend six years for a programme that is scheduled for four years. Some researchers are of the opinion students'University matriculation examinations scores do not significantly predict their First Year Grade Point Average (FYGA). For example Obioma and Salau (2014) concluded in their study that public examinations such as the ones conducted by WAEC, NECO, NATEB or JAMB are poor predictors of University students' academic performance.This study therefore, examined if UTME, PUME and Post- UTME aggregate scores predict students' first year academic performance. It also investigated 
which of these University examinations (UTME, PUME and Post- UTME aggregate) has the highest predictive value

\section{Research Questions}

This study was guided by the following four (4) research questions.

1) Will students' UTME score predict their first year academic performance?

2) Will students' PUTME scores predict their first year academic performance?

3) Will students' Post UTME aggregate scores predict their first year academic performance?

4) Which of these examinations has the highest predictive value?

\section{Hypotheses}

To further guide the study three (3) hypotheses were formulated.

1) Students' UTME scores will not significantly predict their first year academic performance.

2) Students PUTME scores will not significantly predict their first year academic performance.

3) Students' Post UTME aggregate scores will not significantly predict their first year academic.

\section{Purpose of the Study}

The study was aimed at ascertaining the extent to which UTME, PUTME and Post UTME aggregate scores could predict first year academic performance of students' ofpublic universities in Edo State studentsBesides, it was also aimed at finding out which of the predictors has the highest predictive value.

\section{Methodology}

The design of the study was a correlational survey which was based on the framework of ex-post facto as the data used were obtained from examinations already done by the students. The researcher did not have any influence on the dependent variable (year one students' GPA) and the independent variable (UTME, PUTME and Post UTME aggregate scores)

\section{Population of the Study}

The population of the study was 22,653 representing the total number of students admitted into University of Benin, Benin City and Ambrose Ali University, Ekpoma in the 2012/2013 and 2013/2014 academic sessions.

\section{Sample and Sampling Technique}

The step-wise multi stage sampling technique which involves various sampling stages was adopted and a sample size of 1500 was used for the study.

\section{Research Instrument}

The instrument used for the study was a profoma designed by the researcher. The instrument titled "Institution and Students Data Proforma (ISDP) took cognizance of serial number, name of University, department, sex, UTME, PUTME, Post UTME aggregate scores, and students’ first year GPA.

\section{Validity of the Instrument}

The proforma (ISDP) was face-validated by three experts in Educational Measurement and Evaluation of Faculty of Education, University of Benin.

\section{Reliability of the instrument}

The reliability coefficient of the proforma was not determined since it was only an instrument used for collecting data already in existence.

\section{Method of Data collection}

The UTME, PUTME and Post UTME aggregate scoresand year one students' scores were obtained from both Universities used for the study. This was made possible by the authorities of both universities and the help of course advisers of the students.

\section{Method of Data Analysis}

The three hypotheses were tested at 0.05 alpha level significant using simple linear regression statistics.

\section{Results}

Results were derived from testing the hypothesis formulated for the study.

Hypthesis 1: Students UTME scores do not significantly predict their first year academic performance. 
Table 1: Regression summary for the predictive value of UTME scores on first year academic performance. ANALYSIS OF VARIANCE

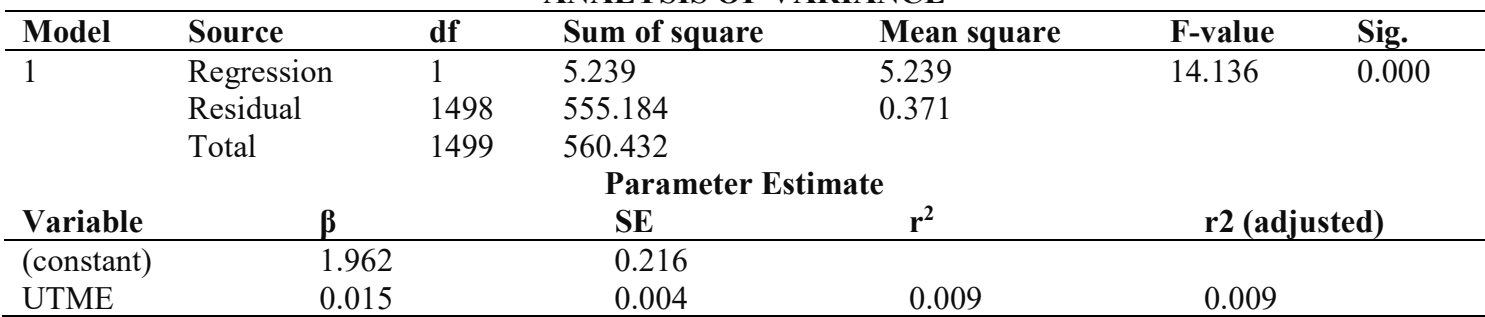

Table 1 revealed significant prediction of UTME for year one students' academic performance. In Table 1, the regression coefficient for UTME was 0.015 and significant at $\mathrm{p}<0.05$ level. The coefficient of determination $\mathrm{r}^{2}$ was founds to be $0.009 \%$ the value revealed that UTME accounted for $0.009 \%$ of the total variance in students' year one academic performance. Table 1 also reveals a $\beta$ weight of 1.962 . The regression equation therefore is $\mathrm{Y}=0.015 \mathrm{x}+1.962$. Besides, table 1 , revealed that analysis of variance for the regression data produced an $\mathrm{f}$-value of 14.136 and significant at $\mathrm{p}<0.05$ level therefore hypothesis 1 is not retained.

Hypothesis 2: Student PUTME scores do not significantly predict their first year academic performance. Table 2: Regression summary for the predictive value of PUTME scores on first year academic performance.

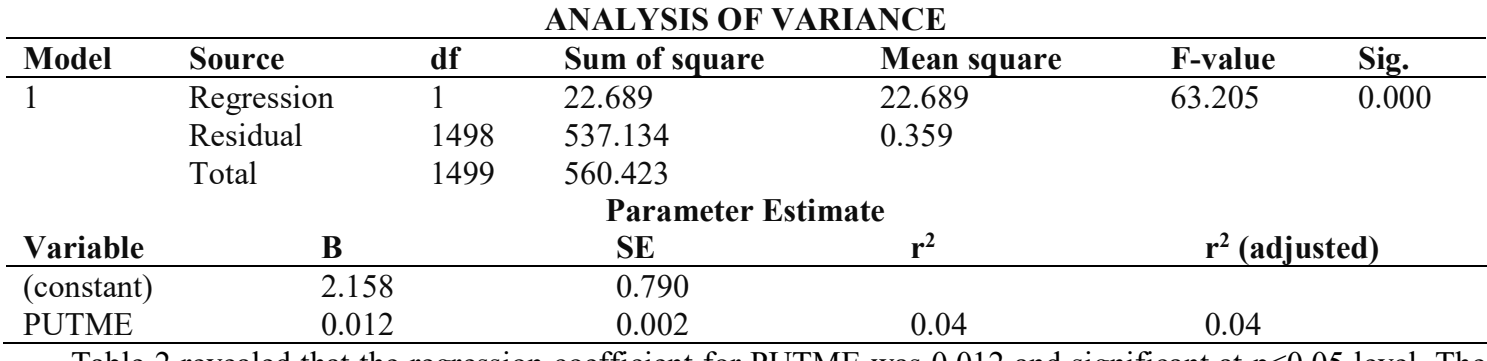

Table 2 revealed that the regression coefficient for PUTME was 0.012 and significant at $\mathrm{p}<0.05$ level. The coefficient of determination $\mathrm{r}^{2}$ was found to be 0.04 , the value revealed that PUTME accounted for $4 \%$ of the total variance in students' year one academic performance. Table 2, also revealed a $\beta$ weight of 2.158 . The regression equation therefore is $\mathrm{Y}=0.012 \mathrm{x}+2.158$. Besides table 2 showed that analysis of variance for the regression data produced in F-value of 63.205 and significant at $\mathrm{p}<0.05$. Therefore, hypothesis 2 is not retained.

Hypothesis 3: Students' Post UTME aggregate scores do not significantly predict their first year academic performance.

Table 3: Regression summary for the predictive value of Post UTME aggregate scores on first year academic performance.

ANALYSIS OF VARIANCE

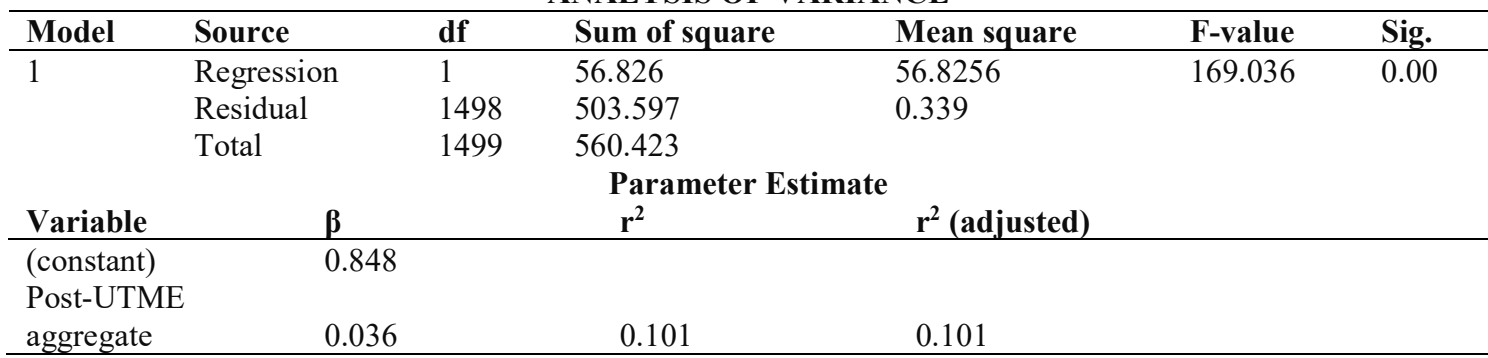

In Table 3 the regression coefficient found for the first Post- UTME aggregate was 0.036 and was significant at $p<0.05$ level. The coefficient of determination $r^{2}$ was found to be 0.101 . this value reveals that Post UTME aggregate accounted for $10.1 \%$ of the total variance of year one students' academic performance. The table also revealed a $\beta$ weight of 0.848 . The regression equation is $Y=0.036 \times 0.848$. Table 3 also revealed that the analysis of variance for the regression data produced and F-value of 169.636 and significant at $\mathrm{p}<0.05$. Thus hypothesis 3 is not retained. The conclusion therefore is that UTME, PUTME and Post-UTME aggregate scores significantly predict year one students' academic performance. For clear visualization the predictability of UTME, PUTME and Post- UTME aggregate scores for first year students' academic performance is represent graphically in figure 1 


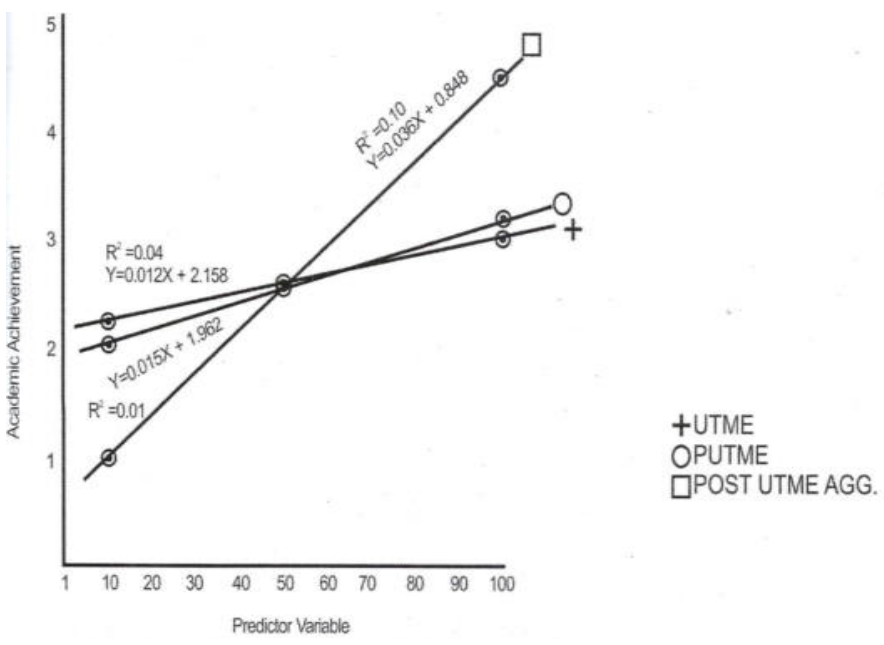

Figure 1: Predictability of UTME, PUTME and Post UTME aggregate scores of first year students' academic performance.

\section{Discussion of findings}

The findings of hypothesis I revealed that UTME significantly predict first year academic performance at $p<0.05$ alpha level. It also revealed that University Tertiary Matriculation Examination (UTME) scores have a low predictive power of 0.009 that is UTME score accounted for only $0.9 \%$ of the total variance. This suggest that $99.1 \%$ of the variance of student's first year academic performance is accounted for by other factors other than UTME scores requirement needed for success in an academic environment such as University. This finding as regards the low predictive value of UTME scores is in agreement with JAMB (2007) who observed that University Matriculation Examination (UTME) scores accounted for $2.8 \%$ in the variance of FGPA of students in Nigerian Universities. Similarly, Omodara (2010) also observed that the predictive strength of UME scores on academic performance of 300 levels students in Nigeria University was low. The low predictive valuing of UTME score may have been affected by several factors such as inadequate facilities, libraries, classroom, crowed academic programme, poor study habit of students etcetera. However, this study is not supported by who the Ayawee (2013) who opined that UTME scores did not significantly predict FGPA of students in Nigerian Universities.

The finding of hypothesis 2 revealed that PUTME significantly predict students first year academic performance at $\mathrm{p}<0.05$ alpha level of significance and that PUTMEhave a low predictive power of 0.04 that is PUTME scores accounted for only $4 \%$ of the total variance of a student's academic performance. This suggests that $96 \%$ of the total variance of students' academic performance is accounted for by other factors. Although PUTME predictive validity value of student's academic performance is low, finding of this study lend support to the rescreening of candidate's through the PUTME screening exercise. For instance, Ifedili andIfedili (2010) reported that student's admitted through the PUTME screening process had better first year grade point Average than those admitted through the UTME. However, the view of Ajaja (2010) is slightly different. Ajaja (2010) who carried out a study to monitor the performance of science education students admitted through post UME screening since its inception in 2005/2006 found out that PUTME did not better that UME in terms of influencing, student's academic performance. Besides, the finding of the study were not consistent with a similar study by Owie (2010) who reported that PUME scores failed to measure up as a credible predictor of University student's survival as reflected in their first year grades and questioned its relevance for post-secondary admission into Nigeria Institutions.

Finding of hypothesis 3 showed that student's post- UTME aggregate scores predict their first year academic performance. Table 3 revealed that post- UTME aggregate scores of students significantly predict their first year academic performance at $\mathrm{p}<0.05$ alpha level. It revealed that post- UTME aggregate scores of students have a predictive power of 0.101 that is, post- UTME aggregate scores accounted for $10.1 \%$ of the total variance of year one students' academic performance. The result of this study revealed that the average combination of UTME and PUTME scores known as aggregate scores has a higher predictive power than either UTME or PUTME. This result is enough to suggest that using either of them as a pre-selection examination may not be sufficient in it itself. The finding of this study was consistent with JAMB (2007) in which it was reported that the combination of SSCE and UTME had a significant difference in the prediction of FYGPA among students than either of them significantly. Obioma and Salau (2007) had also reported that the combination of School Certificate Examination (SSCE) and UTME yielded a better prediction then anyone variable alone. Therefore, the finding of this study revealed that post- UTME aggregate scores has the highest predictive power and that the combined use of both scores would 
ensure that admission of most qualified candidate are selected into undergraduateprogrammes in Nigeria Universities.

\section{Summary}

The study was carried out to ascertain the extent to which UTME, PUTME and post UTME aggregate scores could predict first year academic performance of students in Public Universities in Edo State and also to find out which of these predictors has the highest predictive power. In order to accomplish this, four research questions were raised and three hypotheses were formulated. Correlational survey which was based on the framework of expostfacto was employed for the study. The population of the study was 22,653 which comprised of all the first year students admitted into University of Benin, Benin City and Ambrose Ail, University Ekpoma in 2012/2013 and 2013/2014 academic sessions. The sample of the study consisted of 1500 students. A step wise multi-stage sampling technique was adopted for the study. The research instrument used for collectiondata was a proforma designed by the researcher. Data collected were analyzed with simple linear regression statistics. All hypotheses were tested at 0.05 alpha level of probability.

\section{The findings of the study revealed that:}

(1)UTME scores predict students' first year academic performance and it accounted for $0.9 \%$ of the total variance of students' first year academic performance and was significant at $\mathrm{p}<0.05$

(2) PUTME scores predict students' first year academic performance and it accounted for $4 \%$ of the total variance of students' first year academic performance and was significant of $p<0.05$

(3) Post UTME aggregate scores predict students' first year academic performance and It accounted for $10.1 \%$ of the total variance of students first year academic performance and was significant of $p<0.05$

(4) Post UTME aggregate score is the best predictor of first year students' academic performance.

\section{Conclusion}

The study investigated the predictive power of University Matriculation Examinations and first year academic performance of students' in Public Universities in Edo State using UTME, PUTME and post PUTME aggregate scores as independent variables and first year academic performance as dependent variable. Based on the findings of the study, it is therefore concluded the UTME, PUTME and post UTME aggregate scores individually predicted academic performance of first year students. However, they individually demonstrated poor prediction of first year students' academic performance and that post- UTME aggregate score is the best predictor of the first year students' academic performance.

\section{Recommendations}

1. Joint Admission and Matriculation Board should improve on the standard and Supervision of UTME since results has shown that UTME has the weakest predictive power of students' first year academic performance.

2. The average of UTME and PUTME known as aggregate score results have shown that it has the best predictive power of students' first year academic performance. This should be retained as a mode of selecting candidates into Nigerian Universities. However, University examination committees should ensure that standard of screening tests are maintained.

\section{REFERENCES}

Adeyemi, T . O., (2009). Mode of entry as a predictor of success in final year bachelor of education degree examination in Ekiti Ondo states, Nigeria. Middle-East Journal of Scientific Research, 4(1),10-19

Afemikhe, O .A. (2008). Selection into Nigerian Universities: Student's assessment of post University matriculation examination. A paper presented at an international conference of IAEA Development, 2(1), 4550

Ajaja, O. P. (2010), Three years of Post UME screening: influence on sciences education students' achievement in Delta State University, Abraka. International Journal of Education Science Kamla-Ramja, Pakistan, 2(1), 29-40.

Ayawei, E.K. (2013). University Matriculation Examination Scores as Predictors of first year grade point average of students in Nigeria Universities. (Unpublished Doctoral Thesis), University of Nigeria, Nsukka.

Ifedili, C. J. A. \&Ifedili, J. C. (2010). An assessment of post University matriculation examination: A case study of University of Benin. Journal of Social Science, 22(2), 101-106 Joint Admission and Matriculation Board (JAMB) (2007). A study of the predictive validity of the

Universities matriculation examination (UME) 1998-2000, Abuja: The research, monitoring and evaluation department of JAMB.

Obioma, G, \&Salau, M. (2007). Predictive validity of public examination: A case study of Nigeria. Paper presented 
at the $33^{\text {rd }}$ annual conference of international association for educational assessment (IAEA) held in Buka, Azerbaijan, September, $16^{\text {th }}-21^{\text {st }}$.

Omodara, M. F. (2010). Assessment of the predictive validity of UME scores on academic performance science University undergraduates. Multidisciplinary Journal of Research Development, 14(1), 66-71.

Opoko, A. ,Alagbe, O. , Aderonmu, P. , Ezema, 1. , \&Oluwtayo, .A. (2014). Entry qualification and academic performance of architecture students in building structures. Preceeding of education 14 conference $7^{\text {th }}-9^{\text {th }}$ July, Barcelona, Spain.

Owie, I (2010), National Examination as predictors of University Survival among undergraduates. Journal of Association for Educational Assessment in African 5: 59-66. 